\title{
Improvement of Rose Achene Germination by Treatment with Macerating Enzymes
}

\author{
Yoshiko Yambe and Kiyotoshi Takeno ${ }^{1}$ \\ Laboratory of Horticultural Science, Faculty of Agriculture, Tohoku \\ University, Tsutsumidori-Amamiyamachi, Aoba-ku, Sendai 981, Japan
}

Additional index words. cellulase, pectinase, Rosa multiflora

\begin{abstract}
The germination percentage of Rosa multiflora Thunb. achenes was greatly increased when they were treated with $1 \%$ Driselase, a macerating enzyme, for 36 hours. The seeds germinated more rapidly when the achenes were treated with the enzyme for a longer period. Treatment with Cellulase Onozuka improved seed germination at a lower concentration than did Driselase. Pure preparations of pectinase and cellulase had effects similar to treatment with the enzymes noted. Treatment with pectinase was more efficient than treatment with cellulase. These enzymes likely loosened the bond between cells along the suture of the pericarp and forced the pericarp to split.
\end{abstract}

We have found that a high percentage of excised Rosa multiflora seeds germinated, although intact achenes failed to germinate even under favorable conditions (Yambe et al., 1992). However, pericarp removal from the small and hard achenes is difficult. Tillberg (1983) failed to remove pericarps from $R$. rugosa Thunb. achenes by chemical scarification with sulphuric acid or physical abrasion with sand. Establishment of a new method for removing pericarps could contribute to solving germination problems in roses.

The rose achene pericarp splits along a suture and separates as germination proceeds. Based on this observation, we assumed that the pericarp could be forced to split by loosening bonds within the middle lamella between cells at the suture and by dissolving the cell walls. Further, we reasoned this loosening and dissolving of the

Received for publication 4 Nov. 1991. Accepted for publication 27 Mar. 1992. The cost of publishing this paper was defrayed in part by the payment of page charges. Under postal regulations, this paper therefore must be hereby marked $a d$ vertisement solely to indicate this fact.

'To whom reprint requests should be addressed. cell wall could be induced by exogenous application of enzymes. Accordingly, we examined the effect of macerating enzymes on the splitting of pericarps and achene germination in $R$. multiflora.

Mature cynarrhodia (hips) of $R$. multiflora were harvested at the experimental farm of Faculty of Agriculture, Tohoku Univ., Sendai, Japan, in Winter 1990. The harvested hips were stored at room temperature, and achenes were excised from the hips immediately before use. All experiments were carried out within a few months after harvest.

The macerating enzymes used were Driselase (Kyowa Hakko Kogyo Co., Tokyo), a product of Basidiomycete fungi with activities similar to cellulase, pectinase, glucanase, xylanase, amylase, and others (Noguchi et al., 1978), and Cellulase Onozuka FA (Yakult Biochemicals Co., Nishinomiya, Japan), a product of Trichoderma viride Pers. ex Gray with activities similar to cellulase, protopectinase, hemicellulase, and others. Purer enzyme preparations used were cellulase (EC. 3.2.1.4) from Aspergillus niger van Tiegh. (Sigma, St. Louis) and pectolyase Y-23 (Seishin Pharmaceutical Co., Tokyo) produced from Aspergillus japonicus Satio. The pectolyase Y-23 consisted of two types of pectinase: endo-polygalacturonase (EC. 3.2.1.15) and endo-pectin lyase (EC. 4.2.2.3) (Ishii and Yokotsuka, 1972,1975). Each enzyme or enzyme preparation was dissolved in $10 \mathrm{~mm} 2-(N$-morpholino)ethansulfonic acid buffer ( $\mathrm{pH} 5.0)$ at $0.05 \%$ to $2 \%(\mathrm{w} / \mathrm{v})$.

Fifty achenes were placed in a test tube containing 10-ml of an enzyme solution. Three tubes (replicates) were prepared for each enzyme at each concentration. The tubes were rotated at $5 \mathrm{rpm}$ on a rotary incubator at $30 \mathrm{C}$ under continuous white light provided from fluorescent tubes. After the enzyme treatment, which lasted $36 \mathrm{~h}$, unless otherwise noted, the achenes were washed with distilled water to remove the enzyme and then tested for germination.

The achenes were placed on filter paper in a petri dish ( $9 \mathrm{~cm}$ in diameter) with $4 \mathrm{ml}$ of distilled water. Achenes from the various tubes were incubated in separate dishes at 25C under continuous white fluorescent light. Percent germination was scored daily for 20 days.

Treatment of achenes with Driselase for $36 \mathrm{~h}$ resulted in splitting of the pericarp along the suture (Fig. 1), and germination in the treated achenes was greatly improved (Fig. 2 ). The percent germination increased with increasing enzyme concentration. Germination began 2 days after the enzyme treatment was terminated, and percent germination reached a maximum at 9 days in achenes that had been treated with $1 \%$ Driselase. Fewer than $10 \%$ of nontreated achenes germinated within the 20 days of the experiment.

Seeds germinated more rapidly the longer
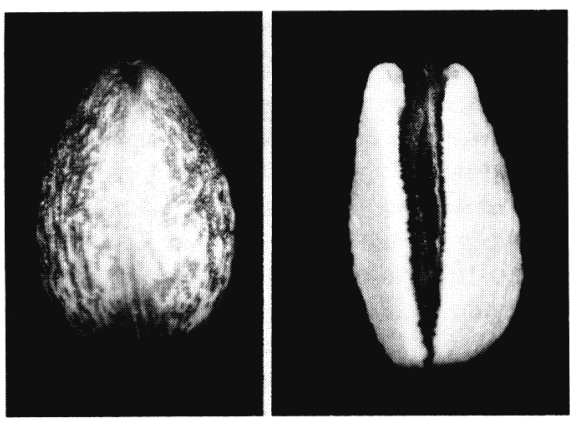

Fig. 1. Achene of Rosa multiflora incubated in buffer (left) and treated with $1 \%$ Driselase (right) for $36 \mathrm{~h}$. 


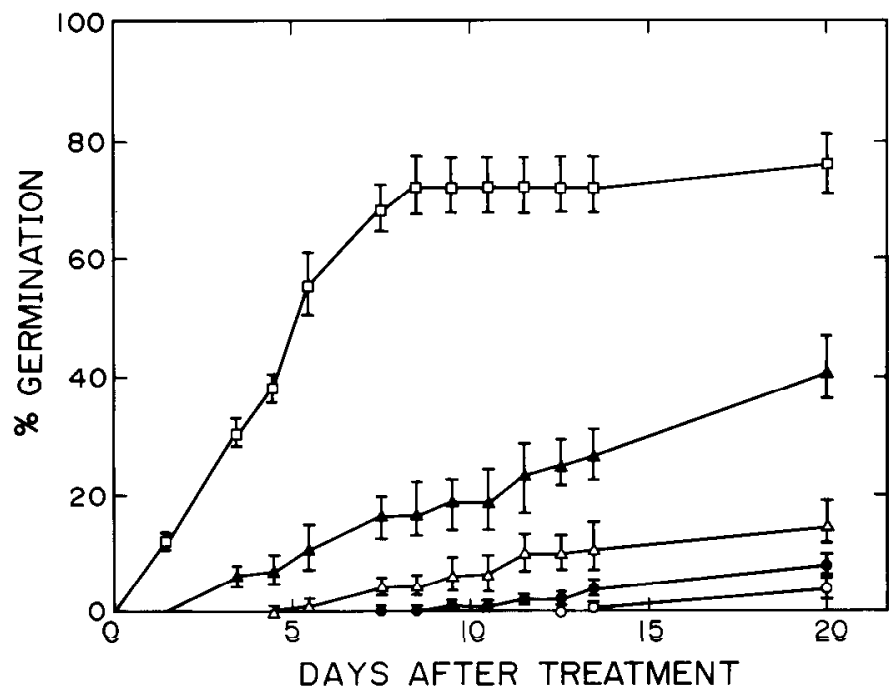

Fig. 2. Time course for germination of Rosa multiflora achenes treated with Driselase at $0 \%(O)$, $0.05 \%(\bullet), 0.1 \%(\Delta), 0.5 \%(\Delta)$, or $1 \%(\square)$ at $30 \mathrm{C}$ for $36 \mathrm{~h}$. After the enzyme treatment, the achenes were tested for germination at $25 \mathrm{C}$ under continuous white light.

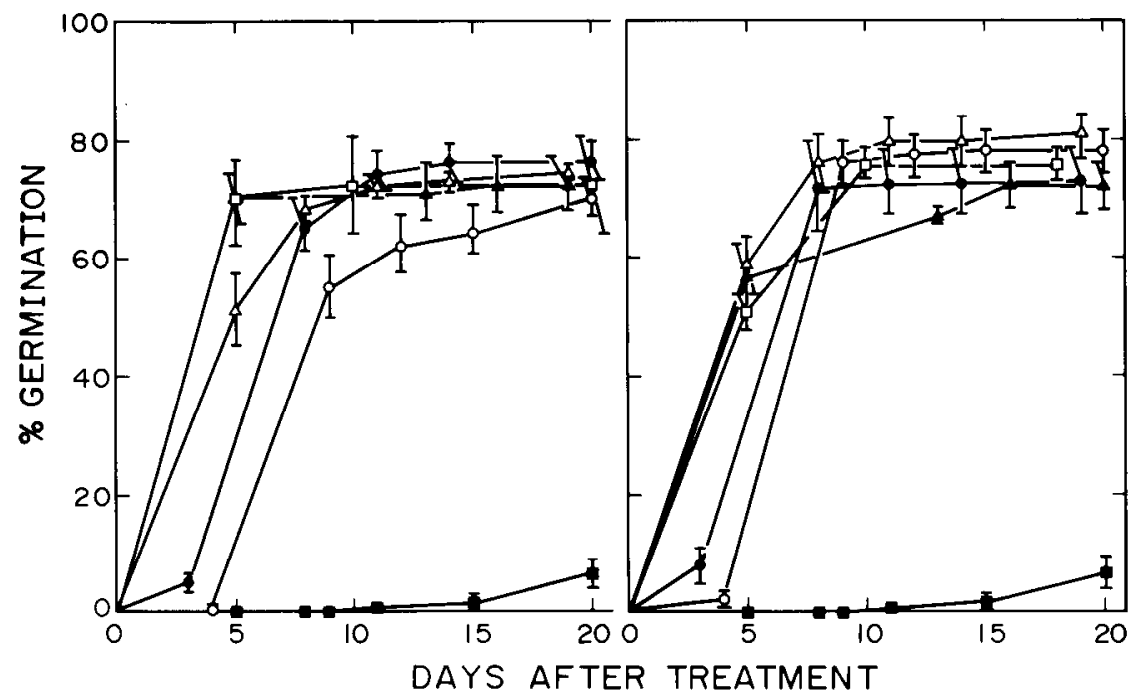

Fig. 3. Time course for germination of Rosa multiflora achenes treated with Driselase at $1 \%$ (left) or $2 \%$ (right) at $30 \mathrm{C}$ for $12(\mathrm{O}), 24(\bullet), 36(\Delta), 48(\boldsymbol{\Delta})$, and $60(\square) \mathrm{h}$. After the enzyme treatment, the achenes were tested for germination at $25 \mathrm{C}$ under continuous white light. Achenes not treated with the enzyme ( $\mathbf{D}$ ) were the control. Zero days = end of treatment.

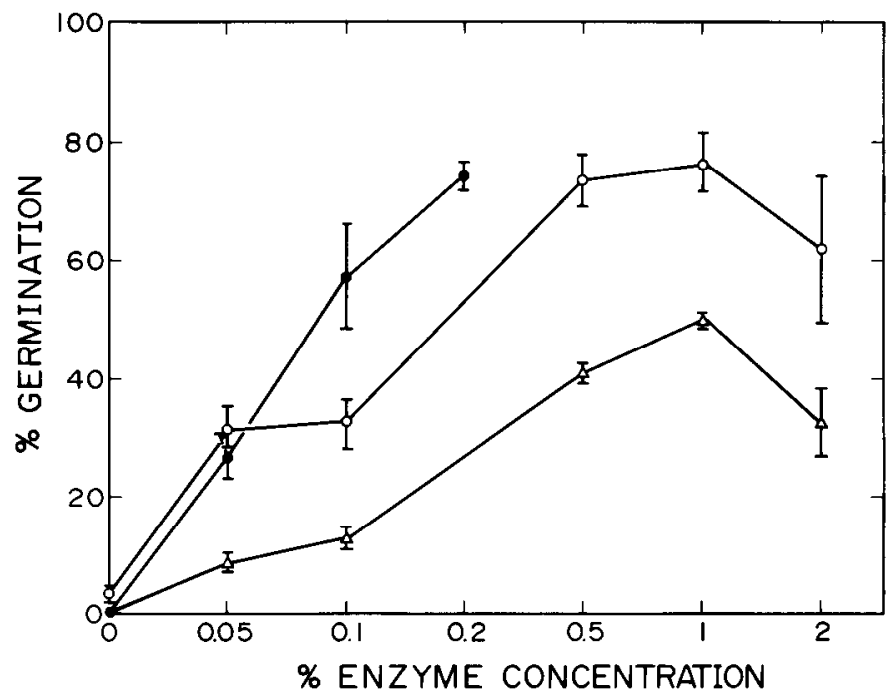

Fig. 4. Effects of Cellulase Onozuka $(O)$, Pectolyase Y-23 $(\bullet)$, and pure cellulase $(\triangle)$ at various concentrations on germination of Rosa multiflora. The achenes were treated with the enzymes at $30 \mathrm{C}$ for $36 \mathrm{~h}$. After the enzyme treatment, the achenes were tested for germination at $25 \mathrm{C}$ under continuous white light. Germination percentages after incubation for 14 days are shown. the treatment period with $1 \%$ Driselase, but the final percent germination was almost the same regardless of treatment duration between 12 and 48 h (Fig. 3, left). Germination of the achenes that had been treated with $2 \%$ Driselase was slightly faster than that of those treated with $1 \%$ Driselase (Fig. 3, right). However, the germination was slightly delayed when the treatment period was prolonged to $48 \mathrm{~h}$.

Cellulase Onozuka also improved germination (Fig. 4). The percent germination increased significantly even at $0.05 \%$, relative to the control. When the enzyme was applied at $2 \%$, the final percent germination decreased significantly.

Pectinase and cellulase (Fig. 4) also increased germination. Pectinase induced the maximum germination percentage at $0.2 \%$, whereas the cellulase induced only $\approx 50 \%$ germination at $1 \%$, the optimal concentration.

The macerating enzymes greatly hastened germination and increased the germination percentage for achenes of $R$. multiflora. The effect of the enzymes was derived mainly from the activities of pectinase and cellulase, but the effect of pectinase was more prominent. These enzymes may have loosened the bond between cells along the suture by degrading the cementing substances and the cell walls (Halmer et al., 1976; Ikuma and Thimann, 1963; Ratner et al., 1969). The loosening of bonds between cells apparently forced the pericarp to split and thus removed a physical barrier to germination. A similar effect has been reported by Lester (198.5), who found that seeds of Solanum carolinense L. and Lycopersicon cheesmanii Riley were induced to germinate in Driselase solution during enzyme etching for taxonomic study. The enzyme treatment etched the cell walls of these hard seeds and softened the seedcoats, permitting the entry of water.

We previously found that $R$. multiforu seed germination was inhibited by abscisic acid (ABA) localized in the pericarps and that leaching the achenes in the presence of activated charcoal improved germination (Yambe et al., 1992). The rose achene pericarp consists of an outer woody layer and an inner fibrous layer (Jackson, 1968). The inner layer may be more permeable to water than the outer layer, as ABA was released more easily from the inner layer than from the outer layer (Yambe et al., 1992). Therefore, the enzyme treatment in the present study may have improved seed germination not only by removing the physical barrier as mentioned above, but also by accelerating the leaching of ABA from the inner surface of the split pericarp.

Imbibition of water by hard seeds after the biological breakdown of the seedcoats by microbial enzymes has been suggested (Egley, 1989). The present study indicates that rose achenes under natural conditions apparently germinate easily when they are buried in soil and infected with microorganisms.

Prolonged treatment with the enzymes or an excessively high concentration of the enzymes suppressed germination. Excessive 
enzyme treatment may have degraded not only the pericarps, but also the seeds. With selection of the optimum enzyme concentration and suitable length of the treatment time, the enzyme treatment likely may be applied to achenes of other rose species to improve germination.

\section{Literature Cited}

Egley, G.H. 1989. Water-impermeable seed coverings as barriers to germination, p. 207-223. In: R.B. Taylorson (ed.). Recent advances in the development and germination of seeds. Plenum Press, New York.

Halmer, P., J.D. Bewley, and T.A. Thorpe. 1976. An enzyme to degrade lettuce endosperm cell walls. Appearance of a mannase following phy- tochrome- and gibberellin-induced germination Planta 130:189-196.

Ikuma, H. and K.V. Thimann. 1963. The role of the seed-coats in germination of photosensitive lettuce seeds. Plant Cell Physiol. 4:169-185.

Ishii, S. and T. Yokotsuka. 1972. Purification and properties of endo-polygalacturonase from Aspergillus japonicus. Agr. Biol. Chem. 36:1885.

Ishii, S. and T. Yokotsuka. 1975. Purification and properties of pectine lyase from Aspergillus japonicus. Agr. Biol. Chem. 39:313.

Jackson, G.A.D. 1968. Hormonal control of fruit development, seed dormancy and germination with particular reference to Rosa. Soc. Chem. Ind. Monogr. 31:127-156.

Lester, R.N. 1985. Seed germination stimulated by enzyme etching. Biochem. Physiol. Pflanzen. 180:709-713.

Noguchi, S., G. Shimura, M. Kawai, Y. Suga, and H. Samejima. 1978. Properties of partially purified cellulolytic and plant tissue macerating enzymes of Irpex lacteus Fr. in special reference to their application. Agr. Biol. Chem. 42:339-345.

Ratner, A., R. Goren, and S.P. Monselise. 1969. Activity of pectin esterase and cellulase in the abscission zone of citrus leaf explants. Plant Physiol. 44:1717-1723.

Tillberg, E. 1983. Levels of endogenous abscisic acid in achenes of Rosa rugosa during dormancy release and germination. Physiol. Plant. 58:243-248.

Yambe, Y., Y. Hori, and K. Takeno. 1992. Levels of endogenous abscisic acid in rose achenes and leaching with activated charcoal to improve the germination. J. Jpn. Soc. Hort. Sci. (In press.) 